\title{
THE INFLUENCE OF CLIMATIC CONDITIONS ON OENOLOGICAL PARAMETERS OF SOME WINE CULTIVARS FROM DIFFERENT ROMANIAN VINEYEARD
}

\author{
P.A. Onache1* ${ }^{*}$ D.I. Sumedrea ${ }^{1}$, A. Florea ${ }^{1}$ and A. Tănase ${ }^{1}$ \\ 1 National Research and Development Institute for Biotechnology in Horticulture \\ Ştefănești - Argeş, no. 37, Bucharest - Pitești Street, Argeş County. 117715. Romania \\ *Corresponding author email: anca27il@yahoo.com
}

\begin{abstract}
A study concerning the influence of climatic conditions on the oenological parameters of wine cultivars was carried out using six wine cultivars under the climatic conditions of 2019. Wine samples were taken from Ştefăneşti-Argeş, Babadag and Drăgășani viticultural centres. Determination of the oenological parameters has been made for the following wine cultivars: Riesling Italian, Fetească Regală, Sauvignon Blanc, Fetească Neagră, Merlot and Pinot Noir. The chemical parameters were determined using a Mindray BS 200 oenological analyser and the statistical analysis of the results was carried out using the Duncan test. A correlation was made between the parameters of the six wine cultivars from the three viticultural centres, focusing on the correlations between the total polyphenols of wines and their antioxidant activity.
\end{abstract}

Keywords: climate change, wine cultivar, chemical composition, polyphenols, antioxidant activity

\section{INTRODUCTION}

The global warming has caused many disturbances in the viticultural ecosystems, the vine cultivars being forced to modify their annual cycle of vegetation, with consequences, most often negative, for the quality and quantity of grape production andalsofor the resulting wines (Tănase, 2019). Already, negative effects of climate change in some vineyards on the globe, such as: earlier ripening of grapes, loss of acidity through respiration and a greater accumulation of sugar, were reported. Also, if the harvest takes place earlier than usual (August or September, instead of October in the northern hemisphere) and the vine is not irrigated, dehydrated grapes will result (Onache, 2018).

The quality of the wine is given by the physico-chemical composition of the wine and its organoleptic properties. In case of wine, that has a very complex composition, the quality remains a random feature, difficult to define and to establish (Geana, 2016).

Red wine is a tannic drink, because it contains polyphenols, which is not the case of other alcoholic beverages. Polyphenols are, in fact, very important constituents of wine and a greate interest is related to their antioxidant action. Polyphenols settle the taste and colour of wine. The most sustained beneficial action of polyphenols from wine is their antioxidant effect, which is achieved by the capture by polyphenols of free radicals circulated through the blood. (Woraratphoka, 2007; Valkom, 2007; Yang, 2009; Visnja, 2010; Bunea, 2012). Consequently, a vigorous research activity was initiated regarding the analysis of these 
antioxidants in different grape products and on the preparation of extracts and wines with a high content of phenolic antioxidants (Heinonen, 1998).

\section{MATERIALS AND METHODS}

In this experiment, grape production and the resulted wines of 6 wine cultivars were studied in 3 winegrowing areas.on the specific climatic conditions of the year 2019. The wine cultivars studied were: Riesling Italian, Fetească Regală, Sauvignon blanc, Fetească Neagră, Merlot and Pinot Noir. Climate determinations have been made for each vineyard using meteo stations, as fallows: Golesca station ( topographic data: $44^{\circ} 85^{\prime} 75^{\prime \prime} \mathrm{N}$ and $24^{\circ} 95^{\prime} 77^{\prime \prime} \mathrm{E}, 300 \mathrm{~m}$ ); Babadag station (Dobrogea) (topographic data: 44 ${ }^{\circ} 94^{\prime} 05^{\prime \prime} \mathrm{N}$ and $28^{\circ} 65^{\prime} 09^{\prime \prime} \mathrm{E}, 250 \mathrm{~m}$ ) and Drăgăşani station (topographic data $44^{\circ} 69^{\prime} 56^{\prime \prime} \mathrm{N}$ and $24^{\circ} 23^{\prime} 57^{\prime \prime} \mathrm{E}$, $195 \mathrm{~m}$ ). The climate data were collected between January and September 2019.

A very large set of chemical analyses were performed. For each wine was determined the following parameters: minimum alcohol content, total acidityand anthocyanins content. The alcohol content, one of the most important parameters of wine quality, was determined by indirect method (hydrostatic balance method), after prior separation of alcohol from wine by distillation. Acidity provides physico-chemical stability of wine, gives colour, brightness and freshness of taste. To characterize the acidity of wine the following types of acidity were taken into consideration. The determination of total acidity was made by titration with bromothymo lblue(Giosanu, 2011).

The total content of polyphenolic compounds (CTCF) was determined by the Folin-Ciocalteu method. With the help of the oenological analyzer Mindray BS200 the organic acidswere determined. (Ţârdea, 2007).

The samples were analyzed according to the technique reported by Brand-Williams and others (1995), with some modifications. Briefly, 1 volume of sample (5 $\mu \mathrm{L}$ for red wine $[1: 1$, $\mathrm{v} / \mathrm{v}$ with methanol]) was added to 1 volume of 2.2-diphenyl-1picrylhydrazyl (DPPH•) (Sigma) $0.094 \mathrm{mM}$ in methanol up to completing $1 \mathrm{~mL}$. The free radical scavenging activity using the free radical $\mathrm{DPPH} \bullet$ reaction was evaluated by measuring the absorbance at 515 $\mathrm{nm}$ after $60 \mathrm{~min}$ of reaction at $20^{\circ} \mathrm{C}$ using a spectrophotometer. The reaction was carried outin closed Eppendorf tubes shakenat $20^{\circ} \mathrm{C}$ and the results were expressed in gallic acid (Woraratphoka, 2007).

For the statistical interpretation of the results, the data were included in an Excel database and then statistically interpreted with the SPSS 14.0 program, which uses the Duncan test (multiple range test) for a 5\% statistical assurance.All the biochemical determinations were carried out in three repetitions.

\section{RESULTS AND DISCUSSIONS}

The climatic values recorded in Ştefăneşti vineyard centre showed some peculiarities whose effects were found both in the course of the vegetative cycle and especially in the level and quality of the grape harvest. Among these specific features we can mention, as the most significant, the following:the low temperatures in the period of April - May, leading to a delay of the flowering by one week $\left(3^{\circ} \mathrm{C} /\right.$ April $1 \mathrm{st}, 5.9^{\circ} \mathrm{C} /$ May $11^{\text {st }}, 6.1^{\circ} \mathrm{C} /$ May 7 th $)$; the temperature in June didn't exceed $35^{\circ} \mathrm{C}$, until 2 days $\left(37^{\circ} \mathrm{C}\right.$ June 25 and $35.6^{\circ} \mathrm{C}$ June 27)and in July there were not reported very high temperatures (maximum $37.8^{\circ} \mathrm{C} / \mathrm{July} 21$ and July 26); in two months (June and July)the temperatures during the night were quite low $\left(14^{\circ} \mathrm{C}\right.$ /June 03 - June 10 and $8.2^{\circ} \mathrm{C} /$ July 11 ) leding to the extension of the ripening period of the grapes (Table 1). 
Table 1. Temperature dynamic duringApril-August 2019 in the three vineyard centres

\begin{tabular}{|c|c|c|c|c|c|c|c|c|c|}
\hline \multirow[b]{2}{*}{ Month } & \multicolumn{3}{|c|}{ Air temperature } & \multirow[b]{2}{*}{$\begin{array}{c}\text { Rainfal } \\
1 \\
(\mathrm{~mm})\end{array}$} & \multirow[b]{2}{*}{$\begin{array}{l}\text { Huglin } \\
\text { Index }\end{array}$} & \multirow{2}{*}{$\begin{array}{c}\text { Days } \\
\text { without } \\
\text { precipit } \\
\text { ation> } \\
10 \mathrm{~mm}\end{array}$} & \multirow[b]{2}{*}{$\begin{array}{c}\sum \mathrm{T} \\
\text { global } \\
\left({ }^{\circ} \mathrm{C}\right)\end{array}$} & \multirow[b]{2}{*}{$\begin{array}{c}\Sigma \mathrm{T} \\
\text { active } \\
\left({ }^{\circ} \mathrm{C}\right)\end{array}$} & \multirow[b]{2}{*}{$\begin{array}{c}\Sigma \mathrm{T} \\
\text { useful } \\
\left({ }^{\circ} \mathrm{C}\right)\end{array}$} \\
\hline & $\begin{array}{c}\text { T med } \\
\left({ }^{\circ} \mathrm{C}\right)\end{array}$ & $\begin{array}{c}\text { Average } \\
\text { T min } \\
\left({ }^{\circ} \mathrm{C}\right)\end{array}$ & $\begin{array}{c}\text { Average } \\
\text { T max } \\
\left({ }^{\circ} \mathrm{C}\right)\end{array}$ & & & & & & \\
\hline \multicolumn{10}{|c|}{ Drăgǎşani } \\
\hline April & 11.92 & 6.53 & 17.83 & 39.9 & 146.25 & 1 & 357.5 & 314.5 & 64.5 \\
\hline May & 14.08 & 9.42 & 19.06 & 14.9 & 203.67 & - & 436.5 & 436.5 & 166.6 \\
\hline June & 22.81 & 17 & 29.23 & 139.2 & 480.6 & 7 & 684.5 & 684.5 & 384.5 \\
\hline July & 22.82 & 15.84 & 30.16 & 63.8 & 511.19 & 3 & 707.5 & 707.5 & 397.5 \\
\hline August & 25.13 & 17.39 & 32.87 & 1 & 589 & - & 779 & 779 & 469 \\
\hline \multicolumn{10}{|c|}{ Babadag } \\
\hline April & 13.3 & 8.43 & 17.97 & 810.2 & 163.05 & 8 & 401 & 354.5 & 124.5 \\
\hline May & 17.5 & 13.1 & 22.29 & 518 & 241.65 & 4 & 542.5 & 542.5 & 232.5 \\
\hline June & 20.5 & 16.2 & 24.73 & 707.1 & 378.45 & 7 & 614.5 & 614.5 & 314.5 \\
\hline July & 27.3 & 21.45 & 32.42 & 602.7 & 615.66 & 6 & 845 & 614.7 & 304.7 \\
\hline August & 27.35 & 20.58 & 31.94 & 199.2 & 609 & 3 & 848 & 848 & 538 \\
\hline \multicolumn{10}{|c|}{ Ștefăneşti } \\
\hline April & 11.2 & 5.4 & 19.1 & 42.2 & 171 & 1 & 338.1 & 244.4 & 53.4 \\
\hline May & 16.3 & 9.8 & 24.6 & 93.6 & 323.95 & 2 & 504.1 & 494.5 & 194.5 \\
\hline June & 22.1 & 15.5 & 32.0 & 193.6 & 511.5 & 6 & 664.6 & 664.6 & 364.6 \\
\hline July & 22.2 & 14.5 & 32.2 & 70.6 & 531.95 & 1 & 687.1 & 687.1 & 377.1 \\
\hline August & 24.6 & 15.7 & 35.8 & 6.6 & 626.2 & 0 & 762.1 & 762.1 & 452.1 \\
\hline
\end{tabular}

Huglin Index $=[($ Tmed -10$)+($ Tmax -10$)] / 2 \times$ no.days of the month.

$\Sigma \mathrm{T}$ global $=$ sum of average positive daily temperatures.

$\Sigma \mathrm{T}$ active $=$ sum of average daily temperatures $>10^{\circ} \mathrm{C}$.

$\Sigma \mathrm{T}$ useful $=$ sum of differences between average daily temperature $>10^{\circ} \mathrm{C}$ and the biological threshold for starting in the vegetation of the vine $\left(10^{\circ} \mathrm{C}\right)$.

The climatic data in Drăgăşani vineyard didn't show any peculiarities in terms of temperatures, which were kept within the normal limits, specific for the Drăgăşani area. In March small peculiarities represented by a minimum temperature of $-2^{\circ} \mathrm{C}$ (in March 15) and a maximum of $25^{\circ} \mathrm{C}$ (in March 18) and poor rainfall (only in March 18 were recorded 18.7 $\mathrm{mm}$ ) were noticed. April was characterised by a minimum temperature of $2^{\circ} \mathrm{C}$ (April 3 and 21), a maximum of $25^{\circ} \mathrm{C}$ (April 27) and poor precipitation (with $15.4 \mathrm{~mm}$ rain in April 18). In May, climate data remained normal $\left(22-28^{\circ} \mathrm{C}\right)$ for this rain-free area, only on May 31 was recorded a maximum temperature of $20^{\circ} \mathrm{C}$. The ripening period of grapes (June-August) was deficient in terms of precipitation. Concerning the temperatures, only in August there were higher temperatures $\left(36^{\circ} \mathrm{C} /\right.$ August 10 and 11).Climate data from the Dobrogea vineyard showed some peculiarities, such as the low temperature in March $\left(\mathrm{T} \max 5^{\circ} \mathrm{C}\right.$ /March 25) and high rainfall (99.5mm /March 16 and 17; 99.8 mm / March 21and 22). April was evidenced by low maximum temperatures $\left(7-18^{\circ} \mathrm{C}\right)$ and heavy rainfall $(99.8 \mathrm{~mm} /$ April 25. 26 and 29). On May had normal temperatures and heavy rainfall ( $99.5 \mathrm{~mm} /$ May 4, 10, 24 and 31). June recorded high temperatures (above $30^{\circ} \mathrm{C}$ ) and heavy rainfall due to storms (99.3 mm /June 4, 8, 13, 20 and 28). The months of July and August had no specific features in terms of temperatures,but there were storms with high precipitation $(99.5 \mathrm{~mm} / \mathrm{July} 2,13$ 
and 24; $99.0 \mathrm{~mm} /$ August 6 and 26). The statistical analysis of the wines concerned the following biochemical indicators: alcoholic concentration (\% vol), total acidity ( $\mathrm{g} / \mathrm{L}$ tartaric acid), dry extract $(\mathrm{g} / \mathrm{L})$, reducing sugars $(\mathrm{g} / \mathrm{L})$, the content in polyphenols (mg GAE/L) and their antioxidant activity (mg GAE/L).

Table 2 shows the correlations between the indicators taken into study. We can highlight the following items:

- The alcoholic concentration correlates positively, significantly distinct, with the total extract $\left(\mathrm{r}=0.628^{* *}\right)$ and negative with density, total acidity and volatile acidity $(\mathrm{r}=-0.284, \mathrm{r}$ $=-0.298, r=-0.088)$.

Table 2. Matrix of " $r$ " correlation (Pearson correlation coefficients " $r$ ") of the main physical and biochemical indicators (average for the 6 wine cultivars from the 3 vineyard centers).

\begin{tabular}{|c|c|c|c|c|c|c|c|c|c|c|}
\hline \multicolumn{2}{|c|}{ Indicators } & $\begin{array}{l}\text { Alch } \\
\text { ool } \\
\text { strei } \\
\text { ght }\end{array}$ & $\begin{array}{c}\text { Dry } \\
\text { extrac } \\
\text { tg/L }\end{array}$ & $\begin{array}{l}\text { Dens } \\
\text { at } 20 \\
\text { degree } \\
\text { sC }\end{array}$ & $\begin{array}{l}\text { Tot. } \\
\text { acid } \\
\text { g/L } \\
\text { AT }\end{array}$ & $\begin{array}{l}\text { Vol. } \\
\text { Acid. } \\
\text { g/L } \\
\text { AA }\end{array}$ & $\begin{array}{l}\text { Sugar } \\
\text { g/L }\end{array}$ & $\begin{array}{l}\text { Total } \\
\text { anthoc } \\
\text { yanins } \\
\text { content } \\
\text { (mg/L) }\end{array}$ & $\begin{array}{c}\text { Total } \\
\text { polyph } \\
\text { enol } \\
\text { conten } \\
\mathrm{t}(\mathrm{mg} \\
\mathrm{GA} / \mathrm{g}) \\
\end{array}$ & $\begin{array}{c}\text { Antiox } \\
\text { Activit } \\
\text { y mg } \\
\text { GAE/L }\end{array}$ \\
\hline $\begin{array}{l}\text { Alchool } \\
\text { Streight }\end{array}$ & $\begin{array}{c}\text { Pearson } \\
\text { Correlation }\end{array}$ & 1 & $\begin{array}{l}.628 \\
(* *)\end{array}$ & -.284 & -.298 & -.088 & .088 & .171 & .106 & .260 \\
\hline $\begin{array}{c}\text { Dry } \\
\text { extract, } \\
\text { g/L }\end{array}$ & $\begin{array}{c}\text { Pearson } \\
\text { Correlation }\end{array}$ & $\begin{array}{l}.628 \\
(* *)\end{array}$ & 1 & .067 & .059 & $\begin{array}{c}-.532 \\
(* *)\end{array}$ & -.048 & $\begin{array}{l}.538 \\
(* *)\end{array}$ & .253 & -.089 \\
\hline $\begin{array}{c}\text { Dens at } \\
20 \\
\text { degrees } \\
\text { C }\end{array}$ & $\begin{array}{c}\text { Pearson } \\
\text { Correlation }\end{array}$ & $\begin{array}{c}- \\
.284\end{array}$ & .067 & 1 & -.054 & .148 & $\begin{array}{l}.814 \\
(* *)\end{array}$ & .116 & $\begin{array}{c}-.439 \\
\left({ }^{*}\right)\end{array}$ & -.072 \\
\hline $\begin{array}{c}\text { Total } \\
\text { acidity } \\
\text { g/L AT }\end{array}$ & $\begin{array}{c}\text { Pearson } \\
\text { Correlation }\end{array}$ & $\begin{array}{c}- \\
.298\end{array}$ & .059 & -.054 & 1 & -.145 & -.281 & .338 & .051 & -.232 \\
\hline $\begin{array}{c}\text { Vol. } \\
\text { acidity } \\
\text { g/L AA }\end{array}$ & $\begin{array}{l}\text { Pearson } \\
\text { Correlation }\end{array}$ & $\begin{array}{c}- \\
.088\end{array}$ & $\begin{array}{c}-.532 \\
(* *)\end{array}$ & .148 & -.145 & 1 & $\begin{array}{l}.477 \\
(* *)\end{array}$ & -.196 & -.084 & $\begin{array}{l}.643 \\
(* *)\end{array}$ \\
\hline $\begin{array}{l}\text { Sugar } \\
\text { g/L }\end{array}$ & $\begin{array}{c}\text { Pearson } \\
\text { Correlation }\end{array}$ & .088 & -.048 & $\begin{array}{l}.814 \\
(* *)\end{array}$ & -.281 & $\begin{array}{l}.477 \\
(* *)\end{array}$ & 1 & -.034 & $\begin{array}{c}-.557 \\
(* *)\end{array}$ & .250 \\
\hline $\begin{array}{l}\text { Total } \\
\text { anthocy } \\
\text { anins } \\
\text { content } \\
\text { (mg/L) }\end{array}$ & $\begin{array}{c}\text { Pearson } \\
\text { Correlation }\end{array}$ & .171 & $\begin{array}{l}.538 \\
(* *)\end{array}$ & .116 & .338 & -.196 & -.034 & 1 & $\begin{array}{l}.474 \\
(* *)\end{array}$ & .116 \\
\hline $\begin{array}{c}\text { Total } \\
\text { polyphe } \\
\text { nol } \\
\text { content } \\
\text { (mg } \\
\text { GA/g) }\end{array}$ & $\begin{array}{c}\text { Pearson } \\
\text { Correlation }\end{array}$ & .106 & .253 & $\begin{array}{c}-.439 \\
\left({ }^{*}\right)\end{array}$ & .051 & -.084 & $\begin{array}{c}-.557 \\
(* *)\end{array}$ & $\begin{array}{l}.474 \\
(* *)\end{array}$ & 1 & $\begin{array}{l}.385 \\
(*)\end{array}$ \\
\hline $\begin{array}{c}\text { Antiox. } \\
\text { activity } \\
\text { mg } \\
\text { GAE/L }\end{array}$ & $\begin{array}{c}\text { Pearson } \\
\text { Correlation }\end{array}$ & .260 & -.089 & -.072 & -.232 & $\begin{array}{l}.643 \\
(* *)\end{array}$ & .250 & .116 & $\begin{array}{c}.385 \\
(*)\end{array}$ & 1 \\
\hline
\end{tabular}


- The sugar content correlates negatively with the total acidity $(r=-0.281)$, the dry extract $(r=-0.048)$ and the anthocyanin content $(r=-0.034)$ and distinctly significant with the total polyphenols $\left(\mathrm{r}=-0.557^{* *}\right)$.

-The $\mathrm{pH}$ correlates positively with the alcoholic content, volatile acidity and antioxidant activity, ( $\mathrm{r}=0.237, \mathrm{r}=0.185$, respectively $\mathrm{r}=0.064$ ) and significant positive to sugar ( $\mathrm{r}=$ $0.432^{*}$ ), which explains that there is a balanced ratio between these indicators.

-Total polyphenols from wine are correlated significantly negative to sugar $\left(\mathrm{r}=-0.557^{* *}\right)$ and to $\mathrm{pH}\left(\mathrm{r}=-0.431^{*}\right)$, but the anthocyanin content $\left(\mathrm{r}=0.474^{* *}\right)$ and antioxidant activity $\left(\mathrm{r}=0.385^{* *}\right)$ are distinct positively correlated with sugar.

In figure 1 is presented the differences between the Dobrogea vineyard and the other two vineyards (Drăgăşani and Ştefăneşti) regarding the alcoholic strength. Concerning Fetească Neagră cultivar from Dobrogea vineyard,the alcoholic strength was around 15.5\% vol., from Ştefăneşti it reached13.15\% vol.and from Drăgăşani vineyard was13.36\% vol. The lowest alcoholic concentrations were found in white wines, especially in Fetească Regală cultivar from Dobrogea vineyard, with $13.0 \%$ vol. and from the Drăgăşani vineyard with $12.85 \%$ vol (fig 1). Regarding the alcoholic strength of the six analysed cultivars in the three geographical areas, the highest alcohol content was recorded at the Pinot Noir wine from Ştefăneşti vineyard centre (fig 2).

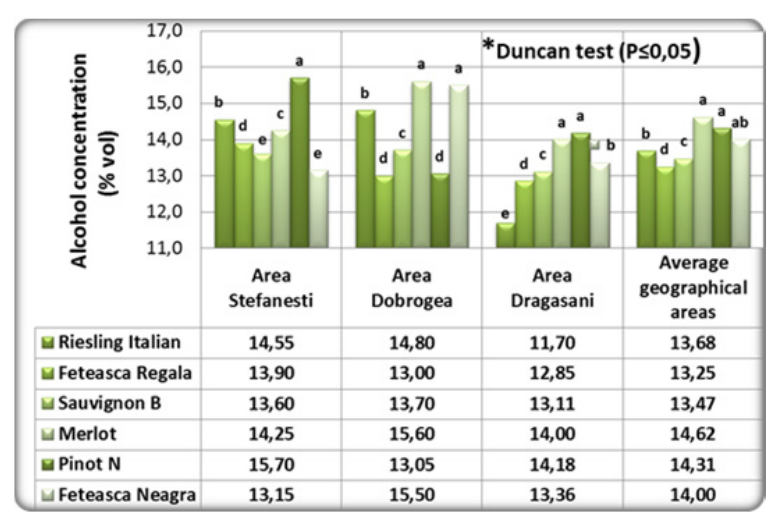

Figure 1. Influence of the cultivar on the alcoholic concentration of wine, depending on the geographical area



Figure 2. Influence of the geographical area on the alcoholic concentration of wine, depending on the cultivar

Figures 3 and 4 show us the influence of the area on the dry extract of wines. Consideringthe average value of the studied cultivars, it can be observed that the highest value of extracts were recorded at Drăgăşani (Merlot $=29.1 \mathrm{~g} / \mathrm{L}$ ) and Dobrogea (Pinot Noir=27.65g/L) vineyards, and the lowest at Ştefăneşti vineyard centre.

The differences of total acidity depend on the pedological composition of the soil in each vineyard and for each cultivar. The lowest value of the average total acidity $(5.21 \mathrm{~g} / \mathrm{L})$ was observed at the cultivars from Dobrogea vineyard (fig. 5, 6).

The $\mathrm{pH}$ of wine depends on the cultivar and on the geographical area. For example for Sauvignon blanc from Ştefăneşti it was 3.92 pH and for Drăgăşani it was 3.05 pH (Fig. 7). Considering the average of the cultivars, the highest $\mathrm{pH}$ was recorded to the Ştefăneşti vineyard centre (3.56 pH) (fig. 8). 




Figure 3. Influence of the cultivar on the dry extract of wine, depending on the geographical area

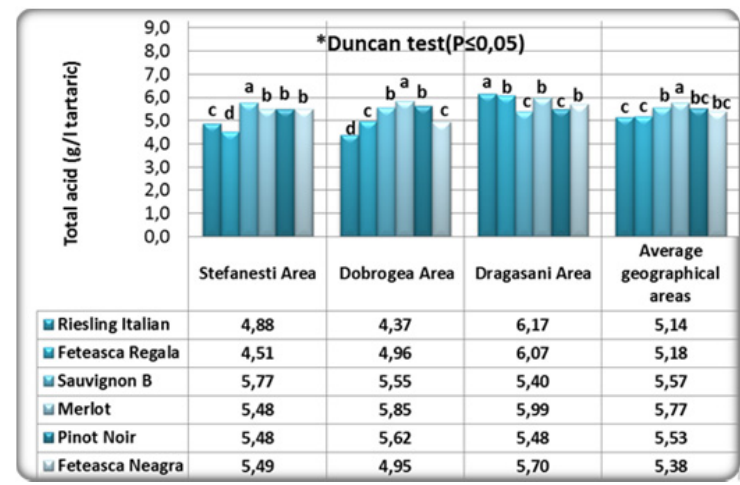

Figure 5. Influence of the cultivar on the total acidity, depending on the geographical area

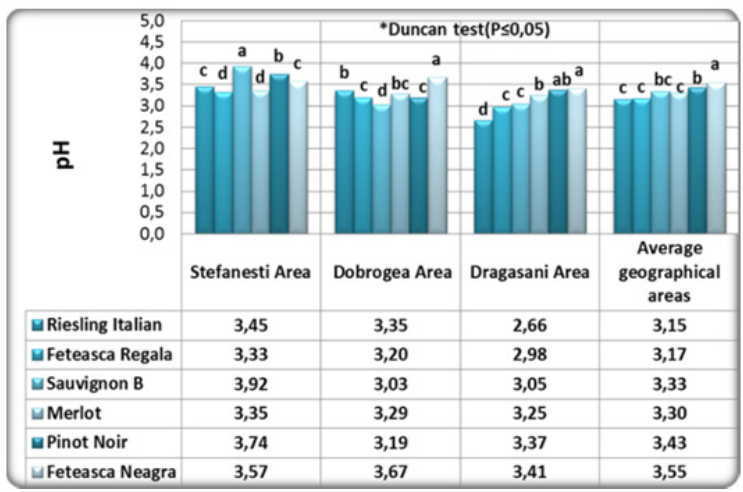

Figure 7. Influence of the cultivar on the $\mathrm{pH}$ of wine, depending on the geographical area



Figure 4. Influence of the geographical area on the dry extract of wine, depending on the cultivar

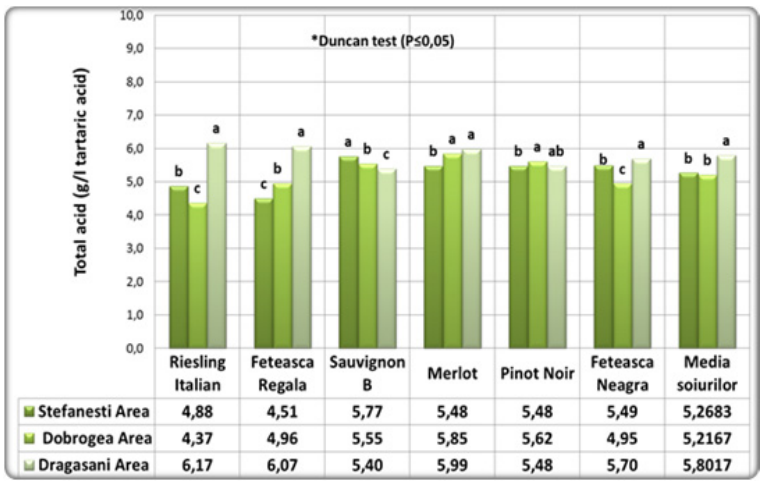

Figure 6. Influence of the geographical area on the total acidity,depending on the cultivar

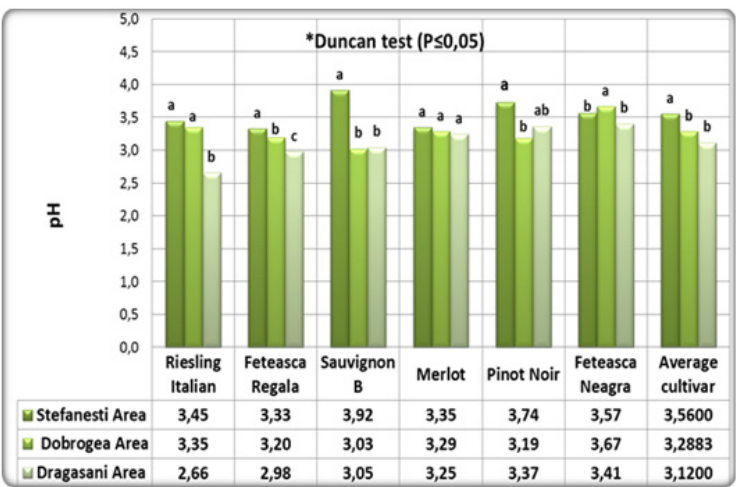

Figure 8. Influence of the geographical area on the $\mathrm{pH}$ of wine, depending on the cultivar

In figures 9 and 10 is showed the influence of the geographical area on the content of total polyphenols in wine, depending on the cultivar. For the red wines, the highest content of total polyphenols was recorded at Fetească Neagră (3549 mg GAE/L) from Dobrogea vineyard, while for Pinot Noir from Ştefăneşti vineyard center was recorded the lowest total polyphenols content (1846 mg GAE/L). 


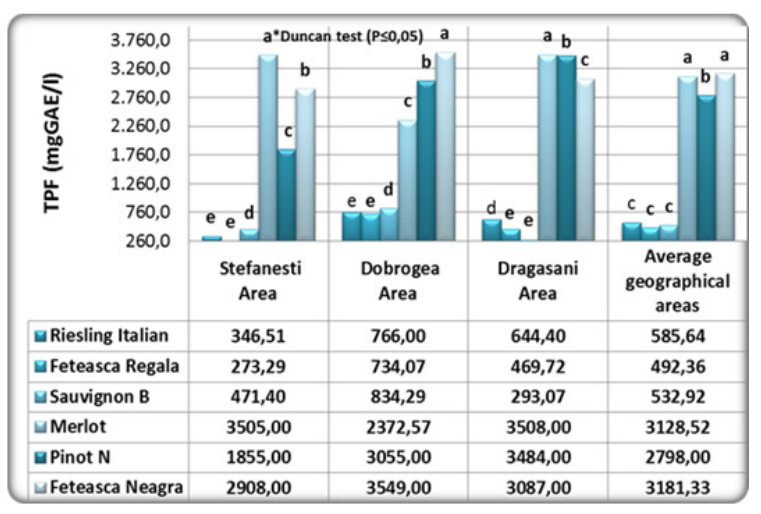

Figure 9. Influence of the cultivar on the content of total polyphenols, depending on the geographical area

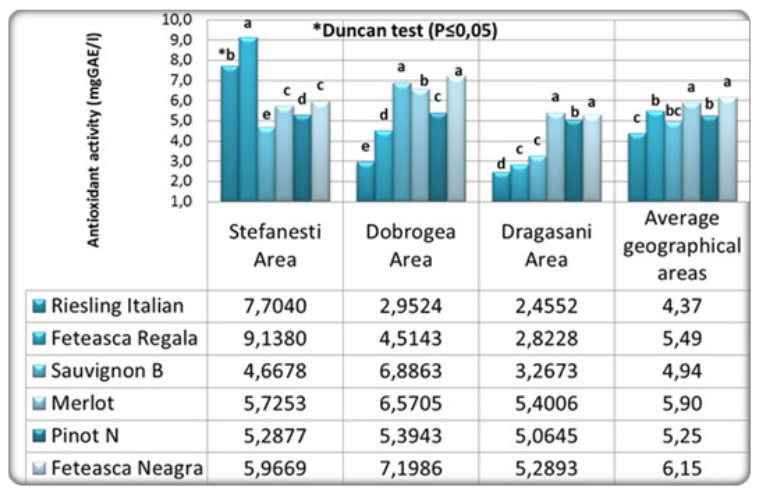

Figure 11. Influence of the cultivar on antioxidant activity, depending on the geographical area

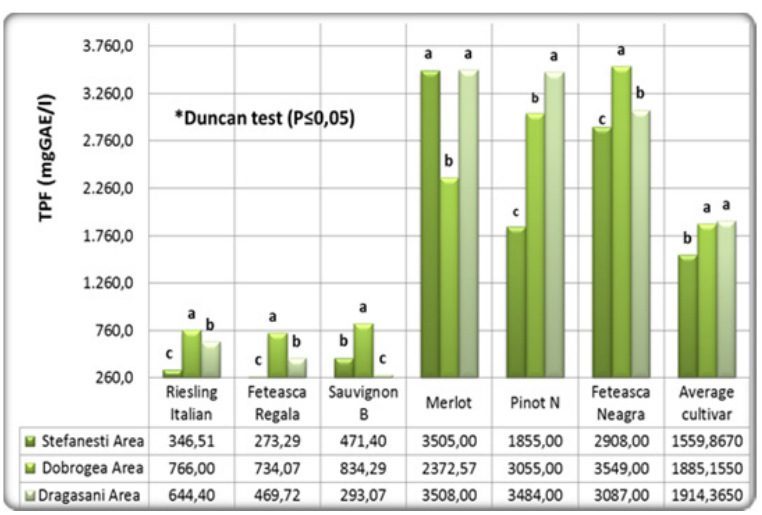

Figure 10. Influence of the geographical area on the content of total polyphenols, depending on the cultivar

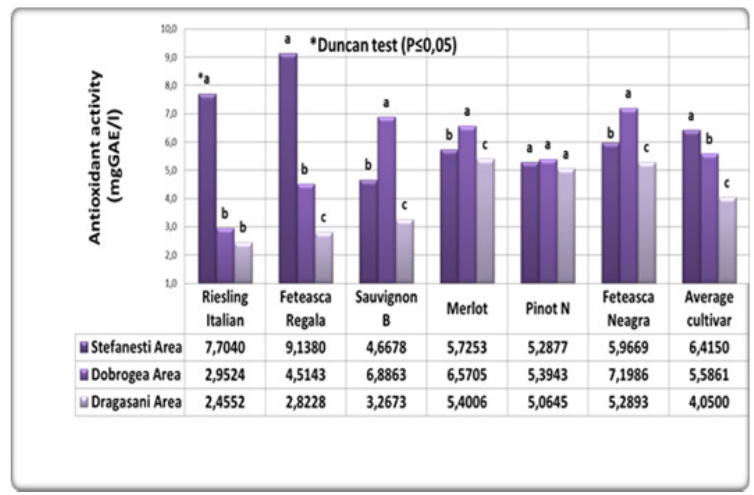

Figure 12. Influence of the geographical area on the antioxidant activity, depending on the cultivar

Antioxidant activity was influenced by the climate and pedological characteristics. The antioxidant activity of the wines is directly proportional to the concentration of total polyphenols in wine. The cultivar with the highest antioxidant activity was Fetească Neagră (1.6582mgGAE/l) from the Dobrogea vineyard (fig. 12). For all the studied cultivars the highest values of this chemical parameterwere recorded at Dobrogea vineyard.

\section{CONCLUSIONS}

- The experimental data showed differences concerning the alcohol concentration for the same cultivar due to the differences of soil, climatic conditions and winemaking technology. - With regard to the alcoholic strength of the sixcultivars analysed in the three geographical areas, the highest alcohol content was recorded for Pinot Noir wine in Ştefănești vineyard centre.

- Among the correlations between the studied indicators we highlight the following: the alcoholic concentration correlates positively, significantly distinct with the total extract $\left(r=0.628^{* *}\right)$ and negative with total acidity and volatile acidity $(r=-0.298, r=-0.088)$; the dry extract of the wines correlates negatively (distinctly significant) with the volatile acidity $\left(r=-0.538^{* *}\right)$ and negative with antioxidant activity $(r=-0.089)$; the total polyphenols from 
wine are significantly negative correlated to sugar $\left(\mathrm{r}=-0.557^{* *}\right)$ and to $\mathrm{pH}\left(\mathrm{r}=-0.431^{*}\right)$, but to the anthocyanin content $\left(\mathrm{r}=0.474^{* *}\right)$ and antioxidant activity $\left(\mathrm{r}=0.385^{* *}\right)$ are distinctly positive correlated.

- Among the studied wines, the wines with high alcoholic concentrations are from Dobrogea vineyard (Merlot 15.6\%vol. Riesling 14.8\%vol), and the wines with the lowest alcoholic concentrations are from Drăgăşani vineyard (Riesling $11.3 \%$ vol, Fetească Regală $12.85 \% \mathrm{vol})$.

- Antioxidant activity was influenced by the climate and pedological characteristics. The antioxidant activity of the wines is directly proportional to the concentration of total polyphenols in the wine. The cultivar with the highest antioxidant activity was Fetească Neagră (1.6582mgGAE/L) from Dobrogea vineyard. For all the studied cultivars, the highest values of this chemical parameterwas recorded at Dobrogea vineyard.

\section{REFERENCES}

1. Bunea C. I., Pop M.. Babes Anca Cristina, Matea C.. Dulf F., Nunea Andrea. 2012 - Carotenoids total polyphenols and antioxidant activity of grapes (Vitis vinifera) cultivated in organic and conventional systems. Chemistry Central Journal. 1752-153x.

2. Geana Elisabeta Irina,Marinescu Adrian, Iordache Andreea Maria, Sandru Claudia, Ionete Roxana Elena, Bala Camelia. 2014 - Differentiation of Romanian Wines on Geographical Origin and Wine Cultivar by Elemental Composition and Phenolic ComponentsFood Anal. Methods DOI 10.1007/s12161-014-9846-2

3. Giosanu D., Vijan L.E. Deliu I. 2011 - The analyses of Physico-Chemical parameters means to appreciate the typicity of some red wine. Food and Environment Safety - Journal of Faculty of Food Engineering.Ştefan cel Mare University - Suceava Year X. No1 Heinonen.I.M.; Meyer.A.S.; Frankel.E.N. Antioxidant activity of berryphenolics on humanlow-density lipoprotein and liposomeoxidation.J. Agr. Food Chem. 1998.46.4107 - 4112. Health Qviz.(Colocviu de sănătate) 1996.rezumat internet: Medical news and alerts.

4. Heinonen. I.M.,Meyer. A.S., Frankel. E.N. Antioxidant activity of berryphenolics on human low-density lipoprotein and liposome oxidation.J. Agr. Food Chem. 1998.46.4107- 4112.Health Qviz.(Cologviu de sanatate) 1996.internet resume: Medical news and alerts

5. OnachePetronaleAnca - 2018- Efectele schimbărilor climatice asupra producției de struguri de vin din zona de sud a României - HORTUS - Revista a horticultorilor și viticultorilor. Nr. 16/2018. Ed. CERES. București. ISSN 2601-9442. ISSN-L 2601-9442.pg 257-265.

6. Tănase. A.,OnachePetronelaAnca,Tănăsescu. C. (2019) - The influence of the climatic conditions on the content of polyphenolic compounds from the main grape cultivars in the Ștefănești vineyard. Tineri cercetători în horticultură, silvicultură şi biotehnologii. vol. Jurnal Of Holticulture. Forestry and Biotechnology 19(4).B+.ISSN 2066-1797.index CABI şi Copernicus

7. Valkom.,Leibfritz D..Moncolj., Cronin M.T.Mazur M..Tesler J.. 2007. Free radicals and antioxidants in normal physiological functions and human disease. Otherwise.International Journal of Biochemistry. Cell Biology 39: 44-84

8. VisnjaKatalinic,Mozina Sonia Smole,Skroza Danijela,Generalic Ivana ,Abramovic Helena, Milos Mladen, LjubenkovIvica, PiskernikS asa. Pezo Ivan,Terpinc Petra,BobanMladen. 2010 - Polyphenolic profile. antioxidant proprieties and antimicrobial activity of grape skin of 14 Vitisviniferacultivars grown in Dalmatia (Croatia). Food Chemistry 119.715-723.

9. Woraratphoka J.,Intarapichet K.O., Indrapichate K. 2007 - Phenolic compounds and antioxidative properties on selected wines from northeast of Thailand. Food Chemistry 104. 1485-1490

10. Yang J.. Martinson T.E., Liu R. H.. 2009 - Phytochemical profiles and antioxidant activities of wine grapes. Food Chemistry. 116. 332-339. 